\title{
Planting Density X Mineral Nutrient Interaction Effect on Biomass Production and Partitioning of Arabica Coffee Cultivars
}

\author{
Wubishet Tamirat \\ Ethiopian Institute of Agricultural Research, Jimma Agricultural Research Center, Jimma, Ethiopia
}

\section{Email address:}

wubishettamirat3@gmail.com

\section{To cite this article:}

Wubishet Tamirat. Planting Density X Mineral Nutrient Interaction Effect on Biomass Production and Partitioning of Arabica Coffee Cultivars. International Journal of Science, Technology and Society. Vol. 9, No. 5, 2021, pp. 228-233. doi: 10.11648/j.ijsts.20210905.14

Received: August 31, 2021; Accepted: October 12, 2021; Published: October 28, 2021

\begin{abstract}
Biomass partitioning is important process for energy distribution among their leaves, stem and roots. The study was designed to evaluate the effect of population densities and fertilizer rates on biomass production and partitioning of Arabica coffee cultivars under nursery conditions. It was conducted at Jimma Agricultural Research Center from (February 29 to October 29), 2018 season. The treatments were arranged by using completely randomized design and a factorial experiment with three replications. Treatments consisted of combinations of two Arabica coffee cultivars (74110 and 75227), four population densities (one, two, three and four plants per polythene tube) and three compound NPK $(22: 6: 12+$ Te) rates (control, $5 \mathrm{~g}$ and $10 \mathrm{~g}$ ). The results showed that, interaction effect of coffee genotypes, population densities and fertilizer rates was highly significant $(\mathrm{P} \leq 0.01)$ for SFW, TFW and TDW, whereas significant $(\mathrm{P} \leq 0.05)$ for RFW, LFW, ShFW, RDW, SDW, LDW and ShDW. The result revealed that, the maximum values of fresh weight (RFW, SFW, LFW, ShFW and TFW) and dry weight (RDW, SDW, LDW, ShDW and TDW) were obtained from treatment combinations of $74110 * \mathrm{PD} 2 * 5 \mathrm{~g}$ of NPK and $75227 * \mathrm{PD} 1 * 5 \mathrm{~g}$ of NPK in cultivar-74110 and cultivar-75227, respectively. Similarly, maximum biomass partitioning was observed from leaf dry weight as compared stem and root dry weight which were treated with $5 \mathrm{~g}$ of NPK for both cultivars. Biomass partitioning optimization is very important to minimize the stress imposed by the limiting resource and more attention should be given on a biotic and biotic factor which affects biomass partitioning under field conditions.
\end{abstract}

Keywords: Biomass Partitioning, Coffee Cultivars, Nutrients, Planting Densities

\section{Introduction}

Biomass partitioning is the process of energy distribution among their leaves, stem, roots and reproductive parts of plant and divided sugar which created by photosynthesis in a way that maximizes growth [1]. Biomass allocation is an important character for the process of characterization of plant physiological ecology. It shows the photosynthates are allocated between above-ground and below-ground biomass [2].

Plants adapt different environmental conditions by distribution of biomass allocation to different parts. It adjusts to variations in resource availabilities by variable partitioning to root and shoot growth [3]. Plants are better able to take resources from their environment and maximize growth by responding to environmental stimuli and partitioning biomass. It partitions biomass in response to limits or excesses in resources: sunlight, $\mathrm{CO}_{2}$, nutrients, and water and its growth is regulated by a constant balance between the partitioning of biomass between plant parts [1]. Phyto-chrome is main light sensing mechanism for plant and it detect of light quality and helps trigger changes biomass partitioning [4]. Leaf is an important source in manufacturing photo assimilates. Plants respond to changing light conditions by adjusting a suite of morpho-physiological traits [5]. According to [6] a 95\% plant biomass is derived from carbohydrates manufactured by green parts by the process of photosynthesis and the remaining 5\% from mineral elements absorbed by the roots. Pervious results indicated that morpho-physiological and chemical leaf traits vary in response to differences in shade management and nutrients [7].

Dry matter production is depending upon leaf area index, structure of the canopy, photosynthetic rates and strength of 
the metabolic sinks [6]. It is varied with accessions, nutrient $[8,9]$ as well as population density or low light. In addition to this, plant hormone plays a major in biomass partitioning; they affect differentiation and growth of cells and tissues by changing the expression of genes and altering morphology [1]. In general, a biotic factor: sunlight, $\mathrm{CO}_{2}$, nutrient and water, and biotic factor: competitions are altered biomass partitioning can be caused by decrease in available resources. The maximum rate of dry matter production within the plant as a whole and partitioning between different parts of the plant has great importance. The study aimed to know the biomass distribution on different plant parts under a biotic and biotic stress conditions. The objective of the study is to evaluate the interaction effect of genotypes, population densities and fertilizer rates on biomass production and partitioning of coffee seedlings under nursery conditions.

\section{Materials and Methods}

\subsection{Description of Experimental Area}

The study was carried out at the Jimma Agricultural
Research Centre (JARC) in Southwestern Ethiopia under nursery for eight months from (February 29 to October 29), 2018. It is located at $7^{\circ} 46^{\prime} \mathrm{N}$ latitude and $36^{\circ} 0^{\prime} \mathrm{E}$ longitude and at an altitude of 1753 meter above sea level. The site receives high amount of rainfall with a mean total of 1556.9 $\mathrm{mm}$ per annum. Its mean minimum and maximum temperatures are $12.77^{\circ} \mathrm{C}$ and $26.14^{\circ} \mathrm{C}$, respectively [5].

\subsection{Experimental Design and Treatments}

The study was carried out using a factorial experiment arranged in completely randomized design with three replications. The treatments consisted of two released Arabica coffee cultivars that represent contrasting growth habits of compact (74110) and open (75227), four plant population densities (one, two, three and four plants per polythene tube) and three compound NPK rates (control (0), $5 \mathrm{~g}$ and $10 \mathrm{~g})$. Compound NPK fertilizer (22: 06: $12+\mathrm{Te})$ with $22 \%$ total $\mathrm{N}, 6 \% \mathrm{P}_{2} \mathrm{O}_{5}, 12 \% \mathrm{~K}_{2} \mathrm{O}$ and trace elements $(\mathrm{Te})$ including $4 \% \mathrm{~S}, 0.15 \% \mathrm{~B}, 0.15 \% \mathrm{Zn}$ and $0.002 \%$ Mo was used. Hence, twenty-four treatment combinations $(2 * 3 * 4)$ were used for the study (Table 1).

Table 1. Total treatment combinations for the study.

\begin{tabular}{|c|c|c|c|c|}
\hline \multirow{2}{*}{ Treatments } & \multicolumn{3}{|c|}{ Main Factors } & \multirow[b]{2}{*}{ Treatment Combinations } \\
\hline & Cultivars & Population Densities & NPK rates (g) & \\
\hline $\mathrm{T} 1$ & \multirow{12}{*}{74110} & \multirow{3}{*}{ PD1 } & 0 & $74110 * \mathrm{PD} 1 * 0 \mathrm{~g}$ NPK \\
\hline T2 & & & 5 & $74110 * \mathrm{PD} 1 * 5 \mathrm{~g} \mathrm{NPK}$ \\
\hline $\mathrm{T} 3$ & & & 10 & $74110 * \mathrm{PD} 1 * 10 \mathrm{~g} \mathrm{NPK}$ \\
\hline $\mathrm{T} 4$ & & \multirow{3}{*}{ PD2 } & 0 & $74110 * \mathrm{PD} 2 * 0 \mathrm{~g} \mathrm{NPK}$ \\
\hline T5 & & & 5 & $74110 * \mathrm{PD} 2 * 5 \mathrm{~g} \mathrm{NPK}$ \\
\hline T6 & & & 10 & $74110 * \mathrm{PD} 2 * 10 \mathrm{~g} \mathrm{NPK}$ \\
\hline $\mathrm{T} 7$ & & \multirow{3}{*}{ PD3 } & 0 & 74110*PD3*0g NPK \\
\hline $\mathrm{T} 8$ & & & 5 & $74110 * \mathrm{PD} 3 * 5 \mathrm{~g} \mathrm{NPK}$ \\
\hline T9 & & & 10 & $74110 * \mathrm{PD} 3 * 10 \mathrm{~g} \mathrm{NPK}$ \\
\hline $\mathrm{T} 10$ & & \multirow{3}{*}{ PD4 } & 0 & $74110 * \mathrm{PD} 4 * 0 \mathrm{~g}$ NPK \\
\hline $\mathrm{T} 11$ & & & 5 & $74110 *$ PD4*5g NPK \\
\hline T12 & & & 10 & 74110*PD4*10g NPK \\
\hline T13 & \multirow{12}{*}{75227} & \multirow{3}{*}{ PD1 } & 0 & $75227 * \mathrm{PD} 1 * 0 \mathrm{~g}$ NPK \\
\hline T14 & & & 5 & $75227 * \mathrm{PD} 1 * 5 \mathrm{~g} \mathrm{NPK}$ \\
\hline T15 & & & 10 & $75227 * \mathrm{PD} 1 * 10 \mathrm{~g} \mathrm{NPK}$ \\
\hline T16 & & \multirow{3}{*}{ PD2 } & 0 & $75227 * \mathrm{PD} 2 * 0 \mathrm{~g}$ NPK \\
\hline T17 & & & 5 & $75227 * \mathrm{PD} 2 * 5 \mathrm{~g}$ NPK \\
\hline T18 & & & 10 & $75227 * \mathrm{PD} 2 * 10 \mathrm{~g} \mathrm{NPK}$ \\
\hline T19 & & \multirow{3}{*}{ PD3 } & 0 & 75227*PD3*0g NPK \\
\hline $\mathrm{T} 20$ & & & 5 & $75227 * \mathrm{PD} 3 * 5 \mathrm{~g} \mathrm{NPK}$ \\
\hline T21 & & & 10 & $75227 * \mathrm{PD} 3 * 10 \mathrm{~g} \mathrm{NPK}$ \\
\hline T22 & & \multirow{3}{*}{ PD4 } & 0 & $75227 * \mathrm{PD} 4 * 0 \mathrm{~g}$ NPK \\
\hline $\mathrm{T} 23$ & & & 5 & $75227 * \mathrm{PD} 4 * 5 \mathrm{~g}$ NPK \\
\hline $\mathrm{T} 24$ & & & 10 & $75227 * \mathrm{PD} 4 * 10 \mathrm{~g}$ NPK \\
\hline
\end{tabular}

Where, PD1, PD2, PD3 and PD4 are represents population density 1, 2, 3 and 4 seedlings per polythene tube, respectively.

\subsection{Experimental Procedures}

The growth medium was prepared from top soil $(0-30 \mathrm{~cm}$ depth) from Jimma (Melko) and sand at 3:1 ratio was used. A conventional black polythene tube with size of $(12 \mathrm{~cm}$ diameter and $22 \mathrm{~cm}$ length) was used and $2 \mathrm{~kg}$ of the soil medium mix was filled, arranged on seed beds and irrigated prior to seed sowing. For each treatment, six polythene tubes were used per plot and the prepared seed from selected of coffee genotypes were sown on each polythene tube following the designed planting density. At two pair of true leaves, the compound NPK fertilizer rates were applied to each pot using ring basal method. All the routine pre-and post-sowing nursery operations including mulching, watering, shading and weed control were uniformly applied as recommended [10]. At the end of experiments seedlings were detached from the soil then washed for root fresh weight, and the samples were separated in to leaf, stem and roots and 
oven-dried at $70^{\circ} \mathrm{C}$ for 24 hours for dry mass, finally fresh and dry biomass data were measured by using sensitive balance [5].

Biomass data: root fresh weight (RFW), stem fresh weight (SFW), leaf fresh weight (LFW), shoot fresh weight (ShFW) $=\mathrm{SFW}+\mathrm{LFW})$ and total fresh weight $(\mathrm{TFW}=\mathrm{RFW}+\mathrm{ShFW})$, root dry weight (RDW), stem dry weight (SDW), leaf dry weight $(\mathrm{LDW})$, shoot dry weight $(\mathrm{ShDW})=\mathrm{SDW}+\mathrm{LDW})$, total dry weight $(\mathrm{TDW})=\mathrm{RDW}+\mathrm{ShDW})$ and biomass partitioning were estimated. All relevant data was summarized and subjected to three-way analysis of variance (ANOVA) using SAS 9.0 version [11]. Treatment mean separations were done by least significant difference (LSD) at $5 \%$ probability level.

Table 2. Effect of coffee cultivars, population densities and fertilizer rates on root fresh weight (RFW), stem fresh weight (SFW), leaf fresh weight (LFW), shoot fresh weight (ShFW) and total fresh weight (TFW) of coffee seedlings.

\begin{tabular}{|c|c|c|c|c|c|}
\hline \multirow{2}{*}{ Treatment Combinations } & \multicolumn{5}{|c|}{ Fresh Biomass } \\
\hline & RFW (g) & SFW (g) & LFW (g) & ShFW (g) & TFW (g) \\
\hline 74110*PD1*0g NPK & $1.07 \mathrm{e}-\mathrm{h}$ & $0.86 \mathrm{efg}$ & $1.58 \mathrm{~g}$ & $2.45 \mathrm{ghi}$ & $3.51 \mathrm{gh}$ \\
\hline 74110*PD1*5g NPK & $1.6 \mathrm{abc}$ & $1.3 \mathrm{bcd}$ & $3.25 \mathrm{de}$ & $4.55 \mathrm{~d}$ & $6.15 \mathrm{cde}$ \\
\hline 74110*PD1*10g NPK & 0.151 & $0.2 \mathrm{ij}$ & $0.33 \mathrm{i}$ & $0.53 \mathrm{j}$ & $0.68 \mathrm{j}$ \\
\hline 74110*PD2*0g NPK & $0.69 \mathrm{~h}-\mathrm{k}$ & $0.78 \mathrm{efg}$ & $1.41 \mathrm{~g}$ & 2.19ghi & 2.88ghi \\
\hline $74110 * \mathrm{PD} 2 * 5 \mathrm{~g}$ NPK & $1.99 \mathrm{a}$ & $2.14 \mathrm{a}$ & $4.37 \mathrm{abc}$ & $6.5 \mathrm{ab}$ & 8.49 \\
\hline $74110 * \mathrm{PD} 2 * 10 \mathrm{~g}$ NPK & $0.44 \mathrm{jkl}$ & $0.38 \mathrm{hij}$ & 1.06ghi & $1.45 \mathrm{ij}$ & $1.87 \mathrm{ij}$ \\
\hline 74110*PD3*0g NPK & $0.98 \mathrm{e}-\mathrm{h}$ & $0.71 \mathrm{e}-\mathrm{h}$ & $1.25 \mathrm{gh}$ & 1.96ghi & $2.95 \mathrm{ghi}$ \\
\hline $74110 * \mathrm{PD} 3 * 5 \mathrm{~g}$ NPK & $1.58 \mathrm{bc}$ & $1.1 \mathrm{cde}$ & $2.93 \mathrm{de}$ & $4.01 \mathrm{de}$ & $5.59 \mathrm{de}$ \\
\hline 74110*PD3*10g NPK & 0.151 & $0.08 \mathrm{j}$ & $0.42 \mathrm{hi}$ & $0.5 \mathrm{j}$ & $0.65 \mathrm{j}$ \\
\hline 74110*PD4*0g NPK & $0.69 \mathrm{~h}-\mathrm{k}$ & $0.56 \mathrm{ghi}$ & $1.2 \mathrm{gh}$ & $1.48 \mathrm{hij}$ & $2.18 \mathrm{hi}$ \\
\hline $74110 * \mathrm{PD} 4 * 5 \mathrm{~g}$ NPK & $1.24 \mathrm{c}-\mathrm{f}$ & $1.27 \mathrm{bcd}$ & $2.89 \mathrm{de}$ & $4.14 \mathrm{~d}$ & $5.38 \mathrm{de}$ \\
\hline 74110*PD4*10g NPK & 0.151 & $0.19 \mathrm{ij}$ & $0.43 \mathrm{hi}$ & $0.62 \mathrm{j}$ & $0.76 \mathrm{j}$ \\
\hline 75227*PD1*0g NPK & $1.13 \mathrm{~d}-\mathrm{g}$ & $1.07 \mathrm{bcd}$ & $2.53 \mathrm{ef}$ & 3.8def & $4.9 \mathrm{ef}$ \\
\hline $75227 * \mathrm{PD} 1 * 5 \mathrm{~g}$ NPK & $1.89 \mathrm{ab}$ & $2.03 \mathrm{a}$ & $5.2 \mathrm{a}$ & $7.23 \mathrm{a}$ & $9.1 \mathrm{a}$ \\
\hline 75227*PD1*10g NPK & 0.131 & $0.38 \mathrm{hij}$ & $1.08 \mathrm{ghi}$ & 1.45hij & $1.58 \mathrm{ij}$ \\
\hline $75227 * \mathrm{PD} 2 * 0 \mathrm{~g}$ NPK & $0.81 \mathrm{~g}-\mathrm{j}$ & $0.97 \mathrm{def}$ & $1.7 \mathrm{fg}$ & $2.67 \mathrm{fgh}$ & $3.49 \mathrm{gh}$ \\
\hline $75227 * \mathrm{PD} 2 * 5 \mathrm{~g}$ NPK & $1.47 \mathrm{bcd}$ & $1.37 \mathrm{bc}$ & $3.62 \mathrm{~cd}$ & $4.99 \mathrm{~cd}$ & $6.46 \mathrm{~cd}$ \\
\hline 75227*PD2*10g NPK & $0.45 \mathrm{i}-1$ & $0.54 \mathrm{ghi}$ & $1.73 \mathrm{fg}$ & 2.26ghi & 2.72ghi \\
\hline 75227*PD3*0g NPK & $0.78 \mathrm{~g}-\mathrm{j}$ & $1.04 \mathrm{c}-\mathrm{f}$ & $1.8 \mathrm{fg}$ & 2.84def & $3.62 \mathrm{fg}$ \\
\hline $75227 *$ PD3*5g NPK & $1.32 \mathrm{~cd}$ & $2.02 \mathrm{a}$ & $4.89 \mathrm{ab}$ & $6.89 \mathrm{ab}$ & $8.21 \mathrm{ab}$ \\
\hline 75227*PD3*10g NPK & $0.44 \mathrm{i}-1$ & $0.68 \mathrm{fgh}$ & $1.58 \mathrm{~g}$ & 2.26ghi & 2.71 ghi \\
\hline $75227 * \mathrm{PD} 4 * 0 \mathrm{~g}$ NPK & $0.84 \mathrm{f}-\mathrm{i}$ & $0.73 \mathrm{e}-\mathrm{h}$ & 0.94ghi & 1.93ghi & 2.77ghi \\
\hline 75227*PD4*5g NPK & $1.64 \mathrm{abc}$ & $1.62 \mathrm{~b}$ & $4.18 b c$ & $5.8 \mathrm{bc}$ & $7.44 b c$ \\
\hline 75227*PD4*10g NPK & $0.34 \mathrm{kl}$ & $0.38 \mathrm{hij}$ & 1.19ghi & 1.57hij & $1.91 \mathrm{ij}$ \\
\hline LSD (5\%) & 0.4 & 0.39 & 0.87 & 1.22 & 1.39 \\
\hline CV (\%) & 21.05 & 25.49 & 24.76 & 24.16 & 20.32 \\
\hline
\end{tabular}

Figures followed by same letters within a column for a given variables are not significantly different at $5 \%$ probability level.

Table 3. Interaction effect of coffee cultivars, population densities and fertilizer rates on root dry weight (RDW), stem dry weight (SDW), leaf dry weight $(L D W)$, shoot dry weight (ShDW) and total dry weight (TDW) of coffee seedlings.

\begin{tabular}{|c|c|c|c|c|c|}
\hline \multirow{2}{*}{ Treatment Combinations } & \multicolumn{5}{|c|}{ Dry Biomass } \\
\hline & RDW (g) & SDW (g) & LDW (g) & ShDW (g) & TDW (g) \\
\hline 74110*PD1*0g NPK & $0.25 \mathrm{~d}-\mathrm{g}$ & $0.27 \mathrm{~d}-\mathrm{g}$ & $0.37 \mathrm{gh}$ & $0.63 \mathrm{gh}$ & $0.88 \mathrm{ghi}$ \\
\hline $74110 * \mathrm{PD} 1 * 5 \mathrm{~g} \mathrm{NPK}$ & $0.37 b c$ & $0.37 \mathrm{c}-\mathrm{f}$ & $0.8 \mathrm{de}$ & $1.17 \mathrm{cde}$ & $1.53 \mathrm{cde}$ \\
\hline 74110*PD1*10g NPK & $0.1 \mathrm{jkl}$ & $0.1 \mathrm{~h}$ & $0.1 \mathrm{k}$ & $0.2 \mathrm{i}$ & $0.3 \mathrm{kl}$ \\
\hline $74110 * \mathrm{PD} 2 * 0 \mathrm{~g}$ NPK & $0.19 \mathrm{~g}-\mathrm{j}$ & $0.24 \mathrm{fg}$ & $0.37 \mathrm{gh}$ & $0.61 \mathrm{gh}$ & $0.79 \mathrm{~g}-\mathrm{j}$ \\
\hline $74110 *$ PD $2 * 5 \mathrm{~g} \mathrm{NPK}$ & $0.393 b$ & $0.57 \mathrm{ab}$ & $1.09 \mathrm{bc}$ & $1.66 \mathrm{ab}$ & $2.06 \mathrm{~b}$ \\
\hline $74110 * \mathrm{PD} 2 * 10 \mathrm{~g}$ NPK & $0.14 \mathrm{ijk}$ & $0.19 \mathrm{gh}$ & $0.28 \mathrm{~g}-\mathrm{k}$ & $0.41 \mathrm{hi}$ & $0.55 \mathrm{i}-1$ \\
\hline $74110 *$ PD3*0g NPK & $0.26 \mathrm{~d}-\mathrm{g}$ & $0.24 \mathrm{efg}$ & $0.32 \mathrm{ghi}$ & $0.57 \mathrm{gh}$ & $0.83 g-j$ \\
\hline $74110 *$ PD3*5g NPK & $0.3 \mathrm{c}-\mathrm{f}$ & $0.36 \mathrm{c}-\mathrm{f}$ & $0.74 \mathrm{e}$ & $1.1 \mathrm{def}$ & $1.4 \mathrm{de}$ \\
\hline $74110 * \mathrm{PD} 3 * 10 \mathrm{~g} \mathrm{NPK}$ & $0.06 \mathrm{kl}$ & $0.07 \mathrm{~h}$ & $0.12 \mathrm{ijk}$ & $0.19 \mathrm{i}$ & 0.251 \\
\hline $74110 * \mathrm{PD} 4 * 0 \mathrm{~g}$ NPK & $0.18 \mathrm{~g}-\mathrm{j}$ & $0.19 \mathrm{gh}$ & $0.25 \mathrm{~h}-\mathrm{k}$ & $0.44 \mathrm{hi}$ & $0.62 \mathrm{ijk}$ \\
\hline $74110 *$ PD4*5g NPK & $0.31 \mathrm{~b}-\mathrm{e}$ & $0.38 \mathrm{~cd}$ & $0.72 \mathrm{e}$ & $1.1 \mathrm{def}$ & $1.41 \mathrm{de}$ \\
\hline $74110 * \mathrm{PD} 4 * 10 \mathrm{~g}$ NPK & 0.051 & $0.07 \mathrm{~h}$ & $0.11 \mathrm{jk}$ & $0.17 \mathrm{i}$ & 0.231 \\
\hline $75227 * \mathrm{PD} 1 * 0 \mathrm{~g}$ NPK & $0.23 \mathrm{e}-\mathrm{h}$ & 0.35 & $0.63 \mathrm{ef}$ & $0.98 \mathrm{ef}$ & $1.22 \mathrm{ef}$ \\
\hline $75227 * \mathrm{PD} 1 * 5 \mathrm{~g}$ NPK & $0.52 \mathrm{a}$ & $0.6 \mathrm{ac}-\mathrm{f}$ & $1.37 \mathrm{a}$ & $1.97 \mathrm{a}$ & $2.48 \mathrm{a}$ \\
\hline $75227 * \mathrm{PD} 1 * 10 \mathrm{~g} \mathrm{NPK}$ & $0.12 \mathrm{jkl}$ & $0.13 \mathrm{gh}$ & $0.27 \mathrm{~g}-\mathrm{k}$ & $0.4 \mathrm{hi}$ & $0.52 \mathrm{jkl}$ \\
\hline $75227 * \mathrm{PD} 2 * 0 \mathrm{~g}$ NPK & $0.24 \mathrm{efg}$ & $0.34 \mathrm{c}-\mathrm{f}$ & $0.45 \mathrm{fg}$ & $0.79 \mathrm{fg}$ & $1.03 \mathrm{fg}$ \\
\hline $75227 * \mathrm{PD} 2 * 5 \mathrm{~g}$ NPK & $0.31 \mathrm{~b}-\mathrm{e}$ & $0.38 \mathrm{cde}$ & $0.95 \mathrm{~cd}$ & $1.33 \mathrm{~cd}$ & $1.64 \mathrm{~cd}$ \\
\hline $75227 * \mathrm{PD} 2 * 10 \mathrm{~g}$ NPK & $0.15 \mathrm{~h}-\mathrm{k}$ & $0.19 \mathrm{gh}$ & $0.46 f g$ & $0.65 \mathrm{gh}$ & $0.8 \mathrm{~g}-\mathrm{j}$ \\
\hline $75227 * \mathrm{PD} 3 * 0 \mathrm{~g}$ NPK & $0.22 \mathrm{f}-\mathrm{i}$ & $0.34 \mathrm{c}-\mathrm{f}$ & $0.47 \mathrm{fg}$ & $0.8 \mathrm{fg}$ & $1.02 \mathrm{fgh}$ \\
\hline
\end{tabular}




\begin{tabular}{llllll}
\hline \multirow{2}{*}{ Treatment Combinations } & Dry Biomass & & & \\
\cline { 2 - 6 } & RDW (g) & SDW (g) & LDW (g) & ShDW (g) & TDW (g) \\
\hline $75227 *$ PD3*5g NPK & $0.33 \mathrm{bcd}$ & $0.56 \mathrm{ab}$ & $1.09 \mathrm{ab}$ & $1.75 \mathrm{a}$ & $2.08 \mathrm{~b}$ \\
$75227 *$ PD3*10g NPK & $0.087 \mathrm{kl}$ & $0.18 \mathrm{gh}$ & $0.41 \mathrm{gh}$ & $0.59 \mathrm{gh}$ & $0.68 \mathrm{hij}$ \\
$75227 *$ PD4*0g NPK & $0.21 \mathrm{ghi}$ & $0.25 \mathrm{~d}-\mathrm{g}$ & $0.31 \mathrm{~g}-\mathrm{j}$ & $0.56 \mathrm{gh}$ & $0.77 \mathrm{~g}-\mathrm{j}$ \\
$75227 *$ PD4*5g NPK & $0.36 \mathrm{bc}$ & $0.45 \mathrm{bc}$ & $0.99 \mathrm{bcd}$ & $1.44 \mathrm{bc}$ & $1.79 \mathrm{bc}$ \\
$75227 *$ PD4*10g NPK & $0.08 \mathrm{kl}$ & $0.1 \mathrm{~h}$ & $0.3 \mathrm{~g}-\mathrm{k}$ & $0.4 \mathrm{hi}$ & $0.48 \mathrm{jkl}$ \\
LSD (5\%) & 0.086 & 0.136 & 0.21 & 0.31 & 0.354 \\
CV (\%) & 23.36 & 29.32 & 23.38 & 23.49 & 20.88 \\
\hline
\end{tabular}

Figures followed by same letters within a column for a given variables are not significantly different at $5 \%$ probability level.

Table 4. Summary of the ANOVA for root fresh weight (RFW), stem fresh weight (SFW), leaf fresh weight (LFW), shoot fresh weight (ShFW), total fresh weight (TFW), root dry weight (RDW), stem dry weight (SDW), leaf dry weight (LDW), shoot dry weight (ShDW) and total dry weight (TDW) of coffee seedlings.

\begin{tabular}{|c|c|c|c|c|c|c|c|c|c|c|c|}
\hline \multirow{3}{*}{ SV } & \multirow{3}{*}{ DF } & \multirow{3}{*}{ RFW } & \multirow{3}{*}{ SFW } & \multicolumn{8}{|c|}{ Mean square } \\
\hline & & & & \multicolumn{4}{|c|}{ Fresh Mass } & \multicolumn{4}{|c|}{ Dry Mass } \\
\hline & & & & LFW & ShFW & TFW & RDW & SDW & LDW & ShDW & TDW \\
\hline $\mathrm{C}$ & 1 & $0.032^{\mathrm{NS}}$ & $1.5^{* * *}$ & $12.14 * *$ & $22.23 * *$ & $23.9 * *$ & $0.007^{\mathrm{NS}}$ & $0.097 * *$ & $0.8^{* *}$ & $1.5^{* *}$ & $1.68 * *$ \\
\hline PD & 3 & $0.123 *$ & $0.2^{*}$ & $1.08^{*}$ & $2.25^{*}$ & $3.37 * *$ & $0.015 * *$ & $0.018^{\mathrm{NS}}$ & $0.09 * *$ & $0.19 * *$ & $0.28 * *$ \\
\hline $\mathrm{F}$ & 2 & $10.27 * *$ & $935^{* *}$ & $581 * *$ & $113.3^{* *}$ & $190.2 * *$ & $0.41 * *$ & $0.68 * *$ & $3.54 * *$ & $7.22 * *$ & $11^{* *}$ \\
\hline $\mathrm{C} * \mathrm{PD}$ & 3 & $0.126^{*}$ & $0.47 * *$ & $1.33^{* *}$ & $3.34 * *$ & $3.89 * *$ & $0.004^{\mathrm{NS}}$ & $0.019^{\mathrm{NS}}$ & $0.08 * *$ & $0.17 * *$ & $0.2 *$ \\
\hline $\mathrm{C}^{*} \mathrm{~F}$ & 2 & $0.034^{\mathrm{NS}}$ & $0.003^{\mathrm{NS}}$ & $0.54^{\mathrm{NS}}$ & $0.61^{\mathrm{NS}}$ & $0.54^{\mathrm{NS}}$ & $0.002^{\mathrm{NS}}$ & $0.001^{\mathrm{NS}}$ & $0.033^{\mathrm{NS}}$ & $0.03^{\mathrm{NS}}$ & $0.05^{\mathrm{NS}}$ \\
\hline $\mathrm{PD} * \mathrm{~F}$ & 6 & $0.15^{* *}$ & $0.06^{\mathrm{NS}}$ & $0.48^{\mathrm{NS}}$ & $0.82^{\mathrm{NS}}$ & $1.57 *$ & $0.007 *$ & $0.002^{\mathrm{NS}}$ & $0.03^{\mathrm{NS}}$ & $0.04^{\mathrm{NS}}$ & $0.07^{\mathrm{NS}}$ \\
\hline $\mathrm{C}^{*} \mathrm{PD}^{*} \mathrm{~F}$ & 6 & $0.11 *$ & $0.24 * *$ & $0.68^{*}$ & $1.7 *$ & $2.44 * *$ & $0.007 *$ & $0.019 *$ & $0.04 *$ & $0.12 *$ & $0.17^{* *}$ \\
\hline Error & 46 & 0.037 & 0.06 & 0.28 & 0.56 & 0.66 & 0.003 & 0.007 & 0.02 & 0.038 & 0.05 \\
\hline CV (\%) & & 21.05 & 25.47 & 24.8 & 24.16 & 20.32 & 23.36 & 29.32 & 23.38 & 23.49 & 20.9 \\
\hline
\end{tabular}

$\mathrm{SV}, \mathrm{DF}, \mathrm{C}, \mathrm{PD}, \mathrm{F}, * * *$ and NS represents source of variation, degree of freedom, cultivars, population densities, fertilizer rates, significant at $(\mathrm{P} \leq 0.05)$, highly significant at $(\mathrm{P} \leq 0.01)$ and no significant difference, respectively.

\section{Results and Discussion}

The analysis of variance revealed that the three-way interaction effect of coffee genotypes, population densities and fertilizer rates was highly significant $(\mathrm{P} \leq 0.01)$ for SFW, TFW and TDW, whereas significant $(\mathrm{P} \leq 0.05)$ for RFW, LFW, ShFW, RDW, SDW, LDW and ShDW (Table 4).

The result revealed that, the maximum values of 1.99, 2.14, 4.37, 6.51 and 8.49g of RFW, SFW, LFW, ShFW and TFW, whereas highest values of $0.39,0.57,1.09,1.66$ and $2.06 \mathrm{~g}$ of RDW, SDW, LDW, ShDW and TDW, respectively were obtained from treatment combinations of $74110 * \mathrm{PD} 2 * 5 \mathrm{~g}$ of NPK in cultivar-74110. Similarly, highest values of 1.87 , 2.03, 5.2, 7.24 and 9.1g of RFW, SFW, LFW, ShFW and TFW, whereas maximum values of $0.52,0.6,1.37,1.97$ and $2.48 \mathrm{~g}$ of RDW, SDW, LDW, ShDW and TDW, respectively were obtained from treatment combinations of $75227 *$ PD $1 * 5 \mathrm{~g}$ of NPK in cultivar-75227 (Tables 2 and 3).

Dry weight reflects the functional aspects of all assimilation. Environmental factors affect dry matter biomass partitioning between roots and shoots. The allocation of dry matter among roots and shoots in seedlings developed different it might be related with different population density. Similar reports indicate that variation in morphology and proportions of distribution and allocation of dry matter in the structures [12]. Photosynthetic and nitrogen assimilates are allocated to various parts of the plant in ratios are due to regulatory mechanisms [6]. Cultivar-75227 was highest fresh and dry biomass as compared with cultivar-74110 (Figure 1a) it might be due variations in morphological growth. Highest root and shoot dry matter were obtained from population densities 1 and 2, respectively (Figure 1b). According to [4] plants grown under low light conditions more biomass is allocated to shoots (mainly leaves), but decreases the energy partitioned to the roots because the lower rates of photosynthesis lessen need for water and mineral nutrients. Maximum values for RDW, ShDW and TDW were obtained from $5 \mathrm{~g}$ of NPK in all treatment combinations (Figure 1c), with $106.8,172.13$ and $160.76 \%$ in cultivar-74110, whereas with $126.08,101.02$ and $96.7 \%$ increments over the control for cultivar- 75227 , respectively.

The dry matter partitioning for RDW, SDW, LDW and ShDW which were treated with $5 \mathrm{~g}$ of NPK as derived from Table 3 showed that, biomass partitioning for RDW (19.08$24.88 \%$ and $15.85-20.95 \%)$, SDW (23.61-27.29\% and $23.98-$ 26.94\%), LDW (50.74-53.96\% and 54.96-57.9\%) and ShDW $(75.12-80.92 \%$ and $79.06-84.14 \%)$ were obtained from cultivar-74110 and 75227, respectively. Highest biomass partitioning was observed for LDW as compared with RDW and SDW it might be high leaf weight ratio. Similar finding reported that leaf weight ratio is a determinant of relative growth rate of trees in early stages and also it is determining allocation of biomass to the leaves and other parts. However, higher leaf weight ratio means faster expansion of leaf area and light capture [13]. The leaf areas of coffee plant are indirectly affected by translocation of dry matter to organ parts (root, trunk, leaves and branches) [14].

In addition to this biomass partitioning was increased on ShDW as compared with RDW. Nutrient availability has a 
strong effect on biomass partitioning; fraction of biomass partitioned to shoot increased with increasing both shading and $\mathrm{N}$ supply [15].

Similar findings reported that, as soil fertility increases, biomass is primarily allocated to above ground structures such as leaves and stems [9]. The changes in root: shoot ratio is accompanied by change in nutrient, water availability and carbon metabolism, which affects dry matter partitioning [16].
Application of $10 \mathrm{~g}$ of NPK adversely affected both fresh and dry mass of coffee seedlings. In line with this result, high concentrations of a mineral nutrient that lead to toxicity can have a strong effect on growth and partitioning [17]. This result was in agreement with the findings of [18] who reported that, doses above optimum $\mathrm{N}$ amount from 0.8 or $1.2 \mathrm{~g}$ plant-1 gave rise to $\mathrm{N}$ luxury consumption causing adverse effects on coffee seedling growth.

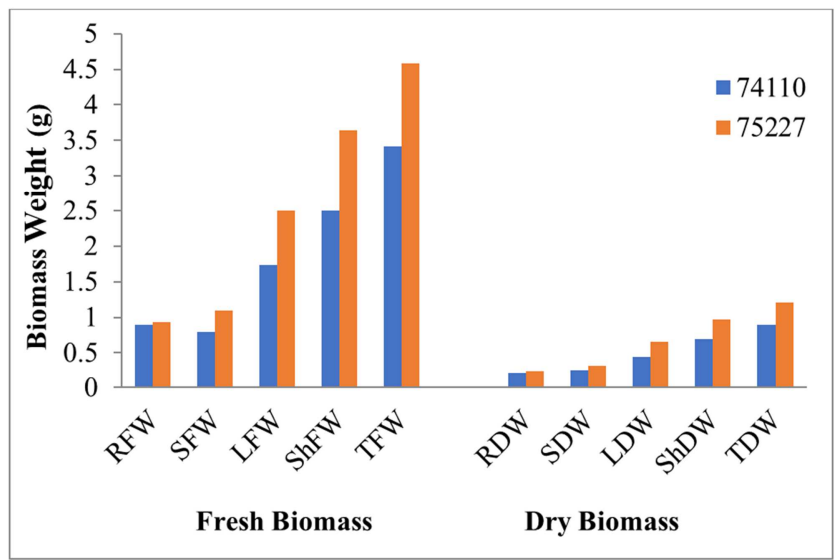

a)

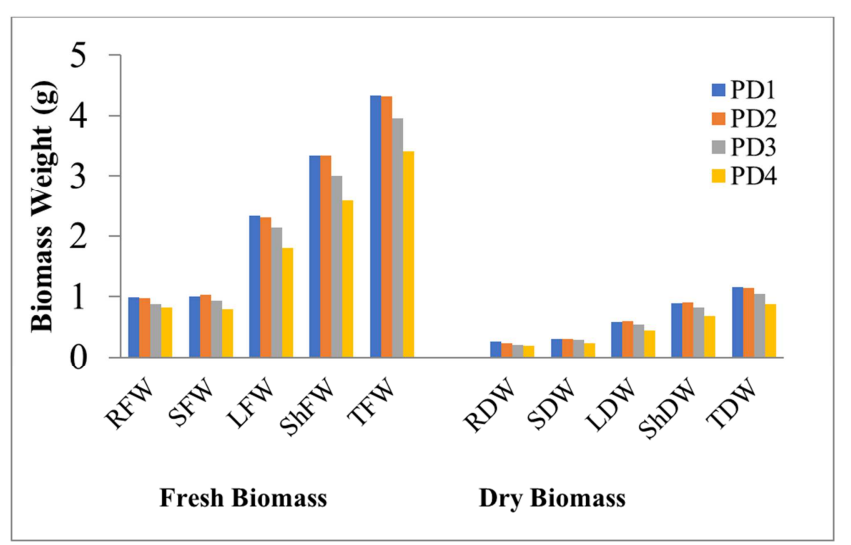

b)

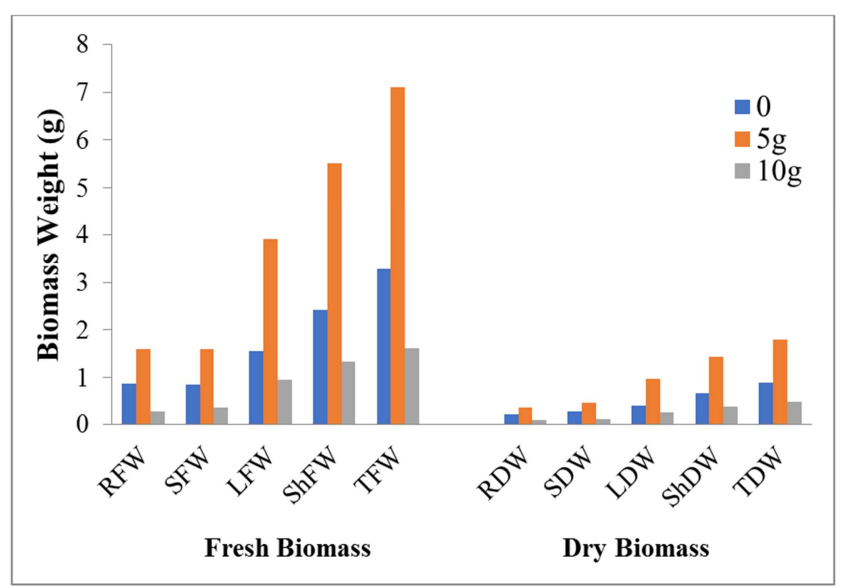

c)

Figure 1. Effect of main factors (a) coffee cultivars, (b) population densities and (c) fertilizer rates) on RFW, SFW, LFW, ShFW, TFW, RDW, SDW, LDW, ShDW and TDW. Where, PD1, PD2, PD3 and PD4 are represents population density 1, 2, 3 and 4 seedlings per polythene tube, respectively. 


\section{Conclusion}

It was observed that highest root and shoot for both fresh and dry weight were obtained from treatment combinations of $74110 * \mathrm{PD} 2 * 5 \mathrm{~g}$ of NPK and $75227 * \mathrm{PD} 1 * 5 \mathrm{~g}$ of NPK in cultivar-74110 and 75227, respectively and similar results were obtained for total fresh and dry mass from the same treatment combinations. In addition to this, maximum biomass partitioning was obtained from leaf as compared with stem and root dry mass. In general, treatment combinations of $74110 * \mathrm{PD} 2 * 5 \mathrm{~g}$ of NPK and $75227 * \mathrm{PD} 1 * 5 \mathrm{~g}$ of NPK in cultivar-74110 and 75227, respectively is best treatment combinations for root, shoot and total dry mass.

\section{Recommendation}

Biomass partitioning optimization is very important to minimize the stress imposed by the limiting resource. Therefore, optimization of population density as well as more attention should be given on a biotic and biotic factor which affects biomass partitioning under field conditions.

\section{Acknowledgements}

I would like to thanks Ethiopian Institute of Agricultural Research (EIAR) for financial support.

\section{References}

[1] Farrar, J. F., and D. L. Jones. 2000. "The control of carbon acquisition by roots." New Phytologist, 147 (1): 43-53.

[2] Mokany, K., Raison, R. J. and Prokushkin, A. S. 2006. Critical analysis of root: shoot ratios in terrestrial biomes. Global change biology, 12 (1): 84-96.

[3] Hodge, A. 2009. Root decisions. Plant Cell Environment, 32 (6): 628-640.

[4] Poorter, H., Niklas, K. J., Reich, P. B., Oleksyn, J., Poot, P. and Mommer, L. 2012. Biomass allocation to leaves, stems and roots: meta-analyses of interspecific variation and environmental control. New Phytologist, 193 (1): 30-50.

[5] Wubishet Tamirat, Amsalu Gobena and Taye Kufa. 2020. Leaf Traits Variation of Arabica Coffee Cultivars in Response to Population Density and Mineral Nutrient. International Journal of Current Research in Life Sciences, 9 (12), 3359-3363.

[6] Taye Kufa., 2012. Biomass production and distribution in seedlings of Coffea arabica genotypes under contrasting nursery environments in southwestern Ethiopia. Agricultural Sciences, 3 (6): 835-843.
[7] Buchanan, S., Isaac, M. E., Van den Meersche, K. and Martin, A. R. 2019. Functional traits of coffee along a shade and fertility gradient in coffee agroforestry systems. Agroforestry Systems, 93 (4): 1261-1273.

[8] Dossa, E. L., Fernandes, E. C. M., Reid, W. S. and Ezui, K., 2008. Above-and belowground biomass, nutrient and carbon stocks contrasting an open-grown and a shaded coffee plantation. Agroforestry Systems, 72 (2), pp. 103-115.

[9] Cambui, C. A., Svennerstam, H., Gruffman, L., Nordin, A., Ganeteg, U. and Näsholm, T. 2011. Patterns of plant biomass partitioning depend on nitrogen source. PLoS One, 6 (4), p. e19211.

[10] Tesfaye Shimber, AlemsegedYilma, Taye Kufa, Endale Taye and AntenehNetsere. 2005. "Coffee seedlings management and production." Amharic version, Ethiopian Agricultural Research Organization, Addis Ababa, Ethiopia. $17 \mathrm{pp}$.

[11] SAS (Statistical Analysis System). 2002. SAS/STAT 9.0 user's guide. Cray, NC: SAS Institute Inc.

[12] Ericsson, T., 1995. Growth and shoot: root ratio of seedlings in relation to nutrient availability. In Nutrient uptake and cycling in forest ecosystems (pp. 205-214). Springer, Dordrecht.

[13] Poorter, H. and Remkes, C., 1990. Leaf area ratio and net assimilation rate of 24 wild species differing in relative growth rate. Oecologia, 83 (4), pp. 553-559.

[14] Minda Tadesse, 2021. Biomass Mass Production and Partitioning in Seedling of Harerghe Coffee Genotypes Under Deficit Irrigation at Jimma, Southwest Ethiopia. American Journal of Life Sciences, 9 (4), pp. 67-72.

[15] Adugna Debela Bote, Zewdneh Zana, Fikre L., Ocho and Jan Vos. 2018. Analysis of coffee (Coffea arabica L.) performance in relation to radiation level and rate of nitrogen supply II. Uptake and distribution of nitrogen, leaf photosynthesis and first bean yields. European Journal of Agronomy, 92, pp. 107-114.

[16] Chaves, A. R., Ten-Caten, A., Pinheiro, H. A., Ribeiro, A. and DaMatta, F. M., 2008. Seasonal changes in photoprotective mechanisms of leaves from shaded and unshaded field-grown coffee (Coffea arabica L.) trees. Trees, 22 (3), p. 351.

[17] Wu, F., Bao, W., Li, F. and Wu, N. 2008. Effects of drought stress and $\mathrm{N}$ supply on the growth, biomass partitioning and water-use efficiency of Sophora davidii seedlings. Environmental and experimental botany, 63 (13): 248-255.

[18] Salamanca-Jimenez, A., Doane, T. A. and Horwath, W. R. 2017b. Coffee response to nitrogen and soil water content during the early growth stage. Journal of Plant Nutrition and Soil Science, 180 (5): 614-623. 